\title{
JIC Green Initiative Project Economic Benefits
}

\author{
Mohammed I. Y. ALEid, Shareef Mohammed El-Shekshaky, Abdul Baseer Mohammed, Fouad \\ Zayadin, and Z Zarshad
}

\begin{abstract}
As the wheel of modernization moves, it is usually accompanied by fuel demand, mainly powering our industry. In Jubail industrial city this is true as well as the petrochemical industry is seen as an opportunity and challenge. In Jubail Industrial College (JIC), as an educational organization, we decided to be part of the sustainable solution as we are located in Jubail Industrial City and we believe that it's our moral responsibility to participate in the change and teach it to the future generation. JIC Green Initiative is our model which integrates solar energy, solid waste recycle, food waste recycle, wind energy, bio-gas and electric vehicles to come up with an example which could be measured and achieved, including all economic benefits, payback period and reduction in carbon foot print in JIC.
\end{abstract}

Index Terms - Green campus, electric vehicles, bio-gas, wind energy.

\section{INTRODUCTION}

In Jubail Industrial College we decided to give a model that every industrial city can follow, so beside the petrochemical pollution from the industrial city we are living in our project will be green eraser to reduce the pollution in our environment.

The project is integrated projects like recycling, Green power generation, implementing EV, education of renewable energy and increase of green landscape see Fig. 1. Green energy include solar panels, wind turbine and bio-gas see Fig. 2 .

To ascertain that JIC green initiative project is credible and applicable, it is required to define the economic benefits of the project, find out the payback period and amount of carbon dioxide $\left(\mathrm{CO}_{2}\right)$ that can be saved in the environment.

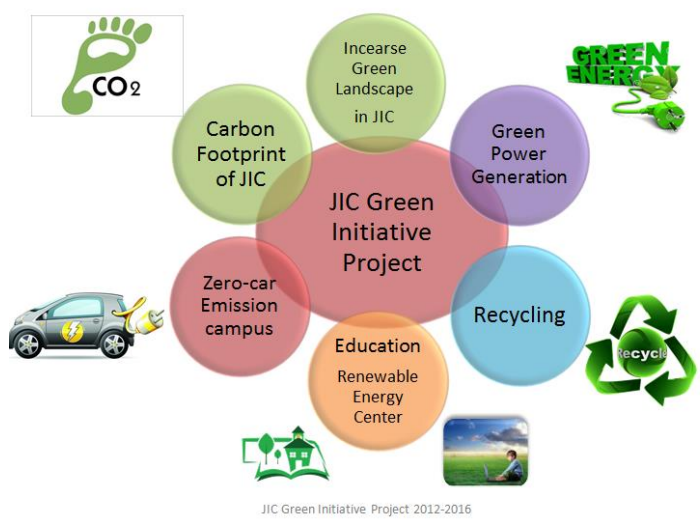

Fig. 1. JIC (Jubail Industrial College) green initiative project.

Manuscript received November 30, 2017; revised February 27, 2018.

The authors are with Jubail Industrial College, Saudi Arabia (e-mail: mohammediyeid@gmail.com,

Zarshad_z@jic.edu.sa, zayadin_ff@jic.edu.sa, baseer_m@jic.edu.sa).
As shown in Fig. 1 above, the JIC Green Initiative Project consists of six segments:

1) Increase Green landscaping

2) Carbon foot print analysis

3) Zero-car emission campus

4) Renewable energy centre

5) Recycling

6) Green Power Generation

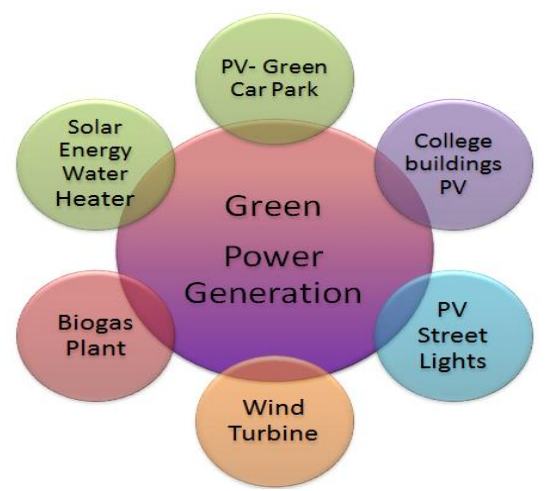

Fig. 2. Green power generation.

In addition, green power generation consists of six segments: 'see Fig. 2.'

1) PV- Green Car Park

2) Solar Energy water heater

3) Biogas Plant

4) Wind Turbine

5) PV street lights

6) College buildings PV

\section{ElECTRIC VeHICLE (EV)}

Electric Vehicle in JIC will result in saving carbon footprint as well as save fuel, taking in consideration current four thousand (4000) cars in JIC campus; new English Language institute's full capacity is about six thousand (6000) students meaning anther 6000 cars, therefore a total of ten thousand $(10,000)$ cars.

Fuel of 10,000 cars will be saved by utilizing the following;

1) Electric bus shuttle

2) Bicycle

3) Shaded walk ways with solar panel collectors

4) Locations that are currently car park will be converted into green Landscaping

5) Tunnel connection between the external car park and the college for safe movement across the road (target future Green Photo Voltaic Car Parking).

With the use of electric vehicle to commute staff and students inside JIC, the expected saving in terms of liters of 
fuel:

- Assuming, on an average, $10 \%$ of fuel tank will be consumed for transportation inside JIC for whole day.

- Then $10 \%$ multiplied by 5 working days in one week, $50 \%$ of your car fuel tank will be saved in one week.

- For four weeks a month, $200 \%$ of fuel tank will be saved or two times filling of your car.

- Taking 2.5 Litre Camry as a model.

- If we consider an average size car Camry 4- cylinder

- $28 \mathrm{MPG}$ Combined city/hwy

- 25 city

- 35 highways

- 17 gallon fuel tank

- Price of 1 gallon of fuel in Saudi Arabia = 0.544 US\$

- A full tank will cost $=16.49$ US\$

- Therefore monthly saving will be $16.49 * 2=32.98$ US $\$$

- For one car saving will be $32.98 * 12$ months $=395.76$ US \$ annual

- For ten thousand cars the saving will be:

- $395.76 * 10,000 \approx 4$ million US dollar annually

Knowing that the cost of the EV system planed for JIC will be $\approx 523,000$ US Dollar. 'See Table I.'

\begin{tabular}{|c|c|c|c|}
\hline Sr. & Items/PS. & Description & Cost (SAR) \\
\hline 1 & 8 & Golf cars & 150,000 \\
\hline 2 & 10 & $\begin{array}{l}\text { E.V. Chargers for } \\
\text { green park }\end{array}$ & 37,775 \\
\hline 3 & 12 & $\begin{array}{l}\text { External parking's } \\
\text { E.V. chargers }\end{array}$ & 98,775 \\
\hline 4 & 20 & $\begin{array}{l}\text { Shuttle bus } \\
14 \text { passenger }\end{array}$ & 843,750 \\
\hline 5 & 10 & $\begin{array}{l}\text { Shuttle bus } \\
14 \text { passenger }\end{array}$ & 421,874 \\
\hline 6 & 1 & $\begin{array}{c}\text { Car port with EV } \\
\text { Charger }\end{array}$ & 247,500 \\
\hline 7 & 2 & $\begin{array}{c}\text { EV maintenance } \\
\text { truck }\end{array}$ & 84,750 \\
\hline 8 & 100 & $\begin{array}{c}\text { Bicycle for } \\
\text { students }\end{array}$ & 75,000 \\
\hline \multicolumn{3}{|c|}{ Total Cost } & $\begin{array}{l}\text { KSA 1,959,424 } \\
\text { US\$ 522,513.07 }\end{array}$ \\
\hline
\end{tabular}

Therefore if we assumed that we initially owned those cars (gasoline) which will cost us to move using them inside the campus 4 million dollar then the paybacks period will be 1.6 months!

Moreover, the saving in $\mathrm{CO}_{2}=3.6$ Tone. [1]

For 10,000 cars, we will be saving the environment an amount of $\mathrm{CO}_{2}$ equivalent to

$$
\text { 3.6 Tone } * 10000=36000 \text { Tone of } \mathrm{CO}_{2} \text {. }
$$

\section{Street Photovoltaic (PV) Lights}

\section{A. Conventional PV Street Lights}

As a very essential part of the whole project; STREET LIGHTS in Jubail Industrial College.

The target is to replace the traditional way of lighting using FOSSIL FUEL by one of the most efficient; green and healthy which is SOLAR way as shown in Fig. 3.

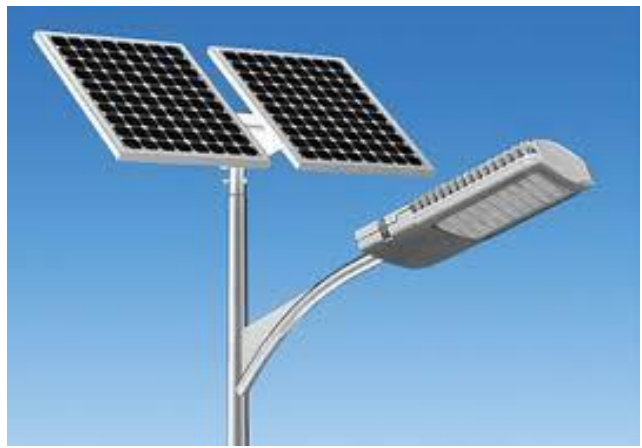

Fig. 3. Conventional solar street light.

As shown in Table II. It highlights after surveying; different Types of Lights, Wattage, Quantity and Cost as per Conventional Solar Street Lights.

The following figures and results must be highly considered:

The Total Cost of lights is 259776 US\$ which means about $1 \mathrm{M} \mathrm{SAR}$

The Total Power is $88.404 \mathrm{~kW}$

The Annual Total Energy is $88.404 * 8 * 366=258846.91$ $\mathrm{kWh}$

The Annual Total Billing is $258846.91 * 32$ (Educational Facilities" 32 Halalah/kWh")

$=8283101.12 \mathrm{H}=82831.01 \mathrm{SAR}=22088.27 \mathrm{US} \$$

It is clear that the payback period will be about 12 years.

It is essential to know how much $\mathrm{CO}_{2}$ emissions prevented:

The $\mathrm{CO}_{2}$ Emission Factor used is $0.527 \mathrm{~kg} / \mathrm{kWh}$

So, $258846.91 \mathrm{kWh} * 0.527=136412.3 \mathrm{~kg}$

\section{B. Led Solar Street Lights:}

With the development of the Conventional (PV) Street Lights, Led (PV) Street Lights became preferable to be used nowadays as shown in Fig. 4.

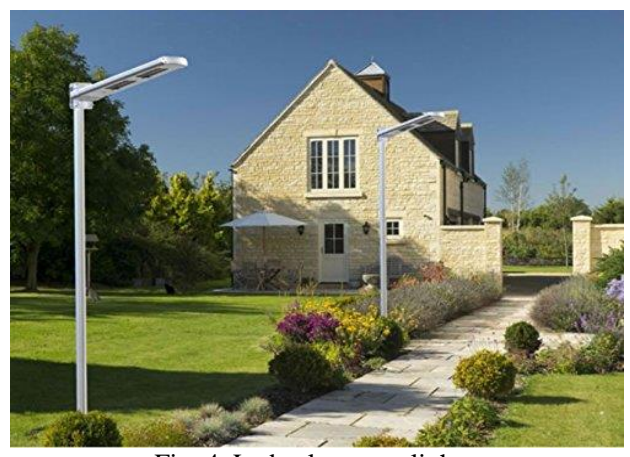

Fig. 4. Led solar street lights.

Table III shows a comparison between Led Lights and Conventional Lights powered by (PV) in terms of wattages.

As shown in Table IV. It highlights after surveying; different Types of Lights, Wattage, Quantity and Cost as per Led (PV) Street Lights.

The following Figures and Results must be highly considered:

The Total Cost of lights is 41865 US\$ $* 3.7506$ which means about 157019 SAR

The Total Power is $48.360 \mathrm{~kW}$. 
TABLE II: DIFFERENT LIGHTS IN JIC CAMPUS

\begin{tabular}{|c|c|c|c|c|c|c|}
\hline S. No. & $\begin{array}{c}\text { Type of } \\
\text { Conventional Lights }\end{array}$ & Wattage & Quantity & $\begin{array}{c}\text { Total Wattage } \\
\text { (W) }\end{array}$ & $\begin{array}{l}\text { Price/Unit } \\
\text { (USD) }\end{array}$ & $\begin{array}{l}\text { Total Price } \\
\text { (USD) }\end{array}$ \\
\hline 1 & Street Lights & $(1 * 400 \mathrm{~W})$ & 125 & 50000 & 1019 & 127375 \\
\hline 2 & Global Lights & $(4 * 100 \mathrm{~W})$ & 4 & 1600 & 1019 & 4076 \\
\hline 3 & Global Lights & $(4 * 15 \mathrm{~W})$ & 50 & 3000 & 175 & 8750 \\
\hline 4 & Global Lights & $(1 * 15 \mathrm{~W})$ & 111 & 1665 & 85 & 9435 \\
\hline 5 & Pathway Lights & $(1 * 80 W)$ & 52 & 4160 & 230 & 11960 \\
\hline 6 & Pathway Lights & $(1 * 125 \mathrm{~W})$ & 111 & 13875 & 350 & 38850 \\
\hline 7 & Bollard Lights & $(1 * 26 W)$ & 24 & 624 & 85 & 2040 \\
\hline \multirow[t]{4}{*}{8} & Parking Shed Lights & $(1 * 40 \mathrm{~W})$ & 337 & 13480 & 170 & 57290 \\
\hline & \multirow[t]{3}{*}{ Total } & \multirow[t]{3}{*}{-} & \multirow[t]{3}{*}{-} & \multirow{3}{*}{\multicolumn{2}{|c|}{$88.404(\mathrm{Kw})$}} & \\
\hline & & & & & & 259776 (USD) \\
\hline & & & & & & $\sim 1 \mathrm{M}(\mathrm{SAR})$ \\
\hline
\end{tabular}

TABLE IV: STATISTICS OF ALL TYPES OF LIGHTS AND COSTS IN JIC CAMPUS WITH LED

\begin{tabular}{|c|c|c|c|c|c|c|c|}
\hline $\begin{array}{r}\text { S. } \\
\text { No. }\end{array}$ & Type of Led Lights & Wattage & $\begin{array}{c}\text { (Led- } \\
\text { amps) (W) }\end{array}$ & Quantity & $\begin{array}{c}\text { Total } \\
\text { Wattage }(\mathbf{W})\end{array}$ & $\begin{array}{r}\text { Price/Unit } \\
\text { (USD) }\end{array}$ & $\begin{array}{c}\text { Total Price } \\
\text { (USD) }\end{array}$ \\
\hline 1 & Street Lights & $(1 * 400 \mathrm{~W})$ & 150 & 125 & 18750 & 52 & 6500 \\
\hline 2 & Global Lights & $(4 * 100 W)$ & 100 & 4 & 400 & 145 & 580 \\
\hline 3 & Global Lights & $(4 * 15 W)$ & 20 & 50 & 1000 & 80 & 4000 \\
\hline 4 & Global Lights & $(1 * 15 W)$ & 10 & 111 & 1110 & 133 & 14763 \\
\hline 5 & Pathway Lights & $(1 * 80 W)$ & 40 & 52 & 2080 & 40 & 2080 \\
\hline 6 & Pathway Lights & $(1 * 125 W)$ & 40 & 111 & 4440 & 30 & 3330 \\
\hline 7 & Bollard Lights & $(1 * 26 W)$ & 15 & 24 & 360 & 49 & 1176 \\
\hline 8 & Parking Shed Lights & $(1 * 40 \mathrm{~W})$ & 60 & 337 & 20220 & 28 & 9436 \\
\hline & Total & - & - & - & $\begin{array}{l}48360(\mathrm{~W}) \\
48.360(\mathrm{Kw})\end{array}$ & - & $\begin{array}{c}41865 \\
\text { (US\$) } \\
157019 \text { (SAR) }\end{array}$ \\
\hline
\end{tabular}

TABLE III: COMPARISON BETWEEN LED AND CONVENTIONAL

\begin{tabular}{cc}
\hline Led Lamps & Conventional Lamps \\
\hline $3 \mathrm{~W}$ & $25 \mathrm{~W}$ \\
\hline $5 \mathrm{~W} / 7 \mathrm{~W}$ & $50 \mathrm{~W}$ \\
\hline $13 \mathrm{~W}$ & $100 \mathrm{~W}$ \\
\hline $40 \mathrm{~W}$ & $150 \mathrm{~W}$ \\
\hline $200 \mathrm{~W}$ & $1000 \mathrm{~W}$ \\
\hline
\end{tabular}

The Annual Total Energy is $48.360 * 8 * 366=141598$ $\mathrm{kWh}$

The Annual Total Billing is $141598 * 32$ (Educational Facilities" 32 Halalah/kWh") [KSA currency]

$$
=4531136 \mathrm{H}=45311.36 \mathrm{SAR}=12081 \mathrm{US} \$
$$

It is clear that the payback period will be about 7 years.

It is essential to know how much $\mathrm{CO}_{2}$ emissions will be prevented:

The $\mathrm{CO}_{2}$ Emission Factor used is $0.527 \mathrm{~kg} / \mathrm{kWh}$, So, $141598 \mathrm{kWh} * 0.527=74622.15 \mathrm{~kg}$

TABLE V: EFFICIENT LED LIGHTS
\begin{tabular}{||c|c|c|}
\hline In Terms Of & Conventional Lights & Led Lights \\
\hline & & \\
\hline Total Cost (US\$) & 259776 & 41865 \\
\hline Total Power (Kw) & 88.404 & 48.360 \\
\hline Annual Total Energy (kWh) & 258846.91 & 141598 \\
\hline Annual Total Billing (US\$) & 22088.27 & 12081 \\
\hline $\mathrm{CO}_{2}$ Emission & 136412.3 & 74622.15 \\
\hline
\end{tabular}

Conclusion related to PV street lights:

Although the (PV) power is already used with the two types of Lights, it is very clear that using the Led Lights is much more efficient than the Conventional Lights as shown in Table V.

Fig. 5 illustrates the eight types of Led Lights that were chosen to replace the Conventional Lights in the project.
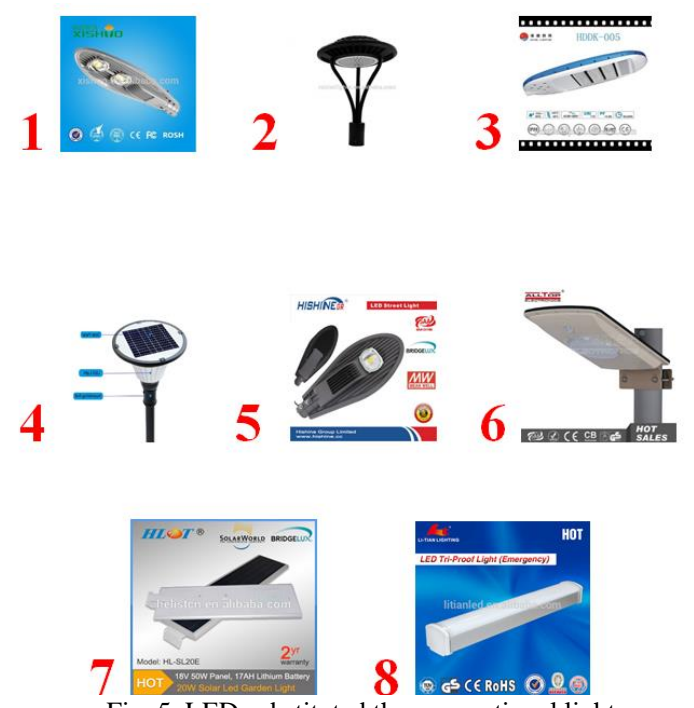

Fig. 5. LED substituted the conventional lights.

\section{Green Photovoltaic CAR PARK (GPCP)}

A main part of the project is to add a shade to a huge car parking and to provide it with solar panels. The two options are usually for photovoltaic system either on grid system or off grid system. For the large area propose $161500 \mathrm{~m}^{2}$ on grid system is the only feasible option as it is almost impossible to 
come up with a battery bank that can serve this large area and also the cost will be high and the maintenance very costly.

The bad news is the on grid power is not yet offered in Saudi Arabia for public use but as the project belong to a governmental segment ( college ) a special permission can be tried, therefore we are assuming here an on grid power system.

For the use of the parking 'see Fig. 6.' which is shading of the car area plus the streets.
Table VI below shows the production, environmental impact, cost and payback period see Table VII. Please note that the following calculations are based on estimated areas, results are adopted from various internet sites regarding productivity, environmental impact, and costs, numbers are sometimes rounded

TABLE VI: POWER PRODUCED BY SOLAR PANELS

\begin{tabular}{cccccccc}
\hline Manufacturer & work area $\left(\mathrm{m}^{2}\right)$ & $\begin{array}{c}\text { Solar panel } \\
\text { area }\end{array}$ & $\begin{array}{c}\text { Panel } \\
\text { power }\end{array}$ & MW(DC) & $\begin{array}{c}\text { MW(AC) } \\
\text { Annual }\end{array}$ & $\begin{array}{c}\text { Tons of } \\
\text { CO }\end{array}$ \\
\hline (1) Anern china & 161477 & 1.64 & $250 \mathrm{w}$ & 24.5 & 19.6 & 28616 \\
\hline $\begin{array}{c}\text { (2) Namakoo } \\
\text { china }\end{array}$ & 161477 & 1.2 & $260 \mathrm{w}$ & 35 & 28 & 40880 & 24773 \\
\hline
\end{tabular}

TABLE VII: COST OF GREEN (PV) CAR PARK

\begin{tabular}{ccccc}
\hline Manufacturer & Electricity Cost in SAR & Electricity Cost in & US (\$) & $\begin{array}{c}\text { Total constructing cost } \\
\text { SAR (\$) }\end{array}$ \\
\hline a. Anern & $9.15 \mathrm{M}$ & $2.4 \mathrm{M}$ & $80 \mathrm{M}(21.35 \mathrm{M})$ \\
\hline b. Namkoo & $13.1 \mathrm{M}$ & $3.5 \mathrm{M}$ & $92 \mathrm{M}(24.5 \mathrm{M})$ \\
\hline
\end{tabular}

Area of parking $=161477 \mathrm{~m}^{2}$,

1) Anern manufacturer [2] has $1.64176 \mathrm{~m} 2$ photovoltaic panel of $250 \mathrm{w}$ power provided by Nearn Industry Group Limited (China);

Area of 250 watt photovoltaic panel $=1.64176 \mathrm{~m}^{2}$ Number of solar panels $=161477 / 1.64176=98356$ panel DC power $=98356 * 250 \mathrm{w}=24589000 \mathrm{w}=24.5 \mathrm{MW}$ AC power $=$ DC power $* 0.8=19.6 \mathrm{MW}$

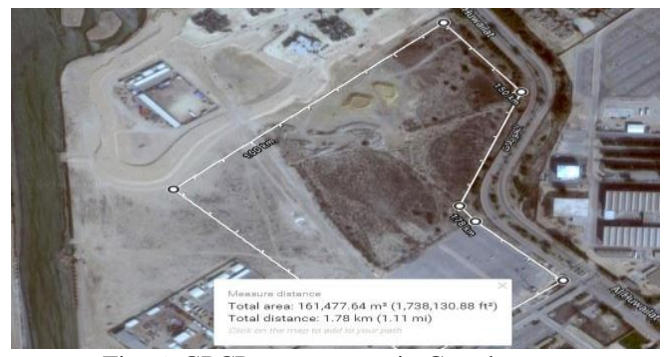

Fig. 6. GPCP area as seen in Google map.

Although sun hours reach up to 8.4 hours in Saudi Arabia eastern province every day but 4 hours are the sun peak hours in Jubail Industrial City then,

Annual AC MWh power generated =

$19.6 \mathrm{MW} * 365$ day in a year * 4 hours peak sun in Jubail city $=28616 \mathrm{MWh}$

About 17000 tons of $\mathrm{CO}_{2}$ will the saving of Green PV Car Park [3].

Cost as per kWatt in Saudi Arabia for Governmental Buildings is 0.32 SAR,

Cost of generated electricity $=28616000 * 0.32=9.15 \mathrm{M}$ $\mathrm{SAR}=2.4 \mathrm{M}$ us $\$$

2) Namkoo manufacturer [4] has $1.2 \mathrm{~m} 2$ photovoltaic panel of $260 \mathrm{w}$ power provided by Namkoo (FoShan)Power Co.,Ltd (China);

Area of 260 watt photovoltaic panel $=1.2 \mathrm{~m}^{2}$

Number of solar panels $=161477 / 1.2=134564$ panel

DC power $=134564 * 260 \mathrm{w}=34986640 \mathrm{w}=35 \mathrm{MW}$

AC power $=$ DC power $* 0.8=28 \mathrm{MW}$

Although sun hours reach up to 8.4 hours in Saudi Arabia eastern province every day but 4 hours is the sun peak hours in Jubail Industrial City then,

Annual AC MWh power generated =

$28 \mathrm{MW} * 365$ day in a year * 4 hours peak sun in Jubail city $=40880 \mathrm{MWh}$

About 24773 tons of $\mathrm{CO}_{2}$ will the saving of Green PV Car Park [3].

Cost as per kWatt in Saudi Arabia for Governmental Buildings is $0.32 \mathrm{SAR}$,

Cost of generated electricity $=40880000 * 0.32=13.1 \mathrm{M}$ $\mathrm{SAR}=3.5 \mathrm{M}$ us $\$$

- Construction cost of solar system of Anern manufacturer according to Anern Industry Group Limited [2] China 871060 \$ as per 1Mw on-grid Solar Power, therefore to the construction cost for $24.5 \mathrm{MW}$ $\mathrm{DC}=24.5 * 871060 \$=21340970 \$=21.35 \mathrm{M} \$$

Payback period $=$ total construction cost $/$ cost of power annually $=21.35 / 2.4=8.9$ years $\approx 9$ years see Table VII

- Construction cost of solar system of Namkoo china [4] $700000 \$=$ as per $1 \mathrm{Mw} 1 \mathrm{Mw}$ on-grid Solar Power, therefore to the construction cost for $35 \mathrm{MW} \mathrm{DC}=35 *$ $700000 \$=24500000 \$=24.5 \mathrm{M} \$$, Payback period $=$ total construction cost/ cost of power annually = $24.5 / 3.5=7$ years see Table VII

Using carbon footprint carbonfund.org calculator [3], will be 17341 ton of $\mathrm{CO}_{2}$ is the saving of pollution when using Anern product and 24773 ton of $\mathrm{CO}_{2}$ is the saving of pollution when using the Namkoo product.

Finally nine years is the payback period for Anern panel whereas seven years is the payback period for Namkoo solar panel see Table VII.

As a result Namkoo system is more suitable as it offer higher efficiency as well as better payback period.

Total parking cost about 13 million US\$ and total power produced is about $40880 \mathrm{MWh}$ annually this power will produce what is equivalent to 3.5 million US\$ annually. The produced power represents $97.3 \%$ of the annual Jubail Industrial College, which is $42000 \mathrm{MWh}$. 
The proposed Green PV Car Parking See Fig. 7 will be the first in the city and will save a lot of power.

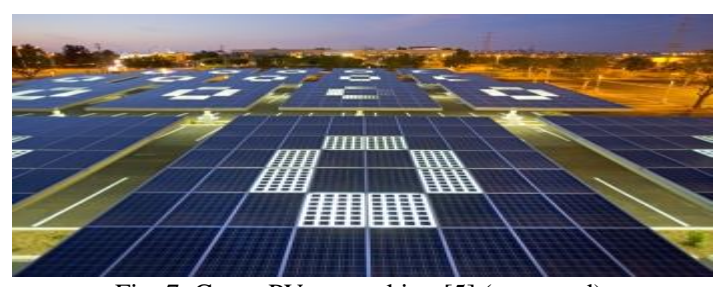

Fig. 7. Green PV car parking [5] (proposed).

\section{SOlar HEATER}

Water heating accounts for about 30 percent of an average household's total greenhouse gas emissions and about the same proportion of total energy use [6]. At Jubail Industrial College (JIC) Campus, water heating by conventional methods consumes about 1.2 MW of electricity and 3500 tonnes of carbon di oxide emissions per year [7]. As a drive to make JIC campus as zero emission places, it is the intent of this research to replace the conventional electric geysers by solar water heating systems. Using solar energy to heat water produces no harmful greenhouse gas emissions. It can provide up to 90 percent of total hot water requirements, depending on the climate and the model of heaters [8].

Cost of solar heater system:

\section{$7,020,750.00 \mathrm{SAR}=1,872,200$ US $\$$}

Power consumption $=1.2 \mathrm{Mw}=1200 \mathrm{Kw}$

Power consumption annually $=1200 \mathrm{Kw} * 8 * 366=$ 3,513,600 Kwh

As the cost of $1 \mathrm{Kwh}=0.32 \mathrm{SAR}$, then Cost of power Annually in SAR

$=3513600 \mathrm{Kwh} * 0.32=1,124,352 \mathrm{SAR}$

Cost of power Annually in US $\$=299,827.2$

Pay pack period $=$ total cost $/$ annual power cost = $1,872,200 / 299,827.2=6.3$ years

\section{ANALYSIS OF PROJECT}

As seen in Table VIII paybacks periods are within margin of 7 years for payback. The total carbon dioxide $\left(\mathrm{CO}_{2}\right)$ savings is 57 thousand ton approximately see Table VIII, an interesting indication comes from the comparison of $\mathrm{CO}_{2}$ savings as seen in Figure 8 and that indicate that $\mathrm{EV}$ or Electric Vehicle saves the environment the most.

\begin{tabular}{ccc}
\multicolumn{2}{c}{ TABLE VIII: $\mathrm{CO}_{2}$ SAVING AND PAYBACK } \\
\hline Item & $\begin{array}{c}\mathrm{CO}_{2} \text { Pollution } \\
\text { Saving(Tone) }\end{array}$ & $\begin{array}{c}\text { Payback period } \\
\text { (Years) }\end{array}$ \\
\hline EV Car & 36000 & 1.6 months \\
\hline Solar Street Light & 136.4 & 7 \\
\hline Green PV Car Park (Namkoo) & 17341 & 7 \\
\hline Solar Heaters & 3500 & 6.3 \\
\hline Total & $\approx 57000$ & -
\end{tabular}

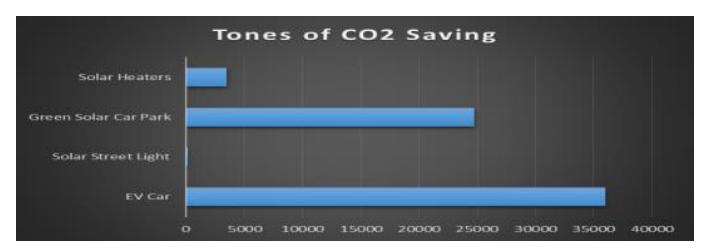

Fig. 8. Comparison between $\mathrm{CO}_{2}$ savings.

\section{CONCLUSION}

JIC Green Initiative can save the environment 57000 ton of $\mathrm{CO}_{2}$ and will cover the electric bill of JIC by $97 \%$, most of the systems including the solar system should payback within 7 years, as a result the project is financially feasible.

\section{ACKNOWLEDGMENTS}

Authors wishing to acknowledge assistance or encouragement from JIC Managing Director of Jubail Industrial College, Chairman of Mechanical Eng. Department and Chairman of Electrical and Electronic Eng. Department.

\section{REFERENCES}

[1] Carbon Offsets To Alleviate Poverty (COTAP) [Web log post]. (Dec 10, 2017). [Online]. Available: http://cotap.org/carbon-emissions-calculator/

[2] Anern manufacturer[Web log post]. (Dec 10, 2017). [Online]. Available: http://www.anern.com/index.html

[3] Carbonfund.org is leading the fight against global warming [Web log post]. (Dec 10, 2017). [Online]. Available: https://carbonfund.org/how-we-calculate/

[4] Namkoo manufacturer[Web log post]. (Dec 10, 2017). [Online] Available: http://www.namkoo-nenergy.com/a/products/1/index.html

[5] Solaripedia is an extensive database for solar architecture [Web log post]. (Dec 10, 2017). [Online]. Available: http://www.solaripedia.com/13/265

[6] LEAP, the Long-range Energy Alternatives Planning System [Web log post]. (Dec 10, 2017). [Online]. Available: www.energycommunity.org/documents/SEA4

[7] [Web log post]. (Dec 10, 2017). [Online]. Available: http://mnre.gov.in/file-manager/UserFiles/brief_swhs.pdf

[8] [Web log post]. (Dec 10, 2017). [Online]. Available: http://ee.ret.gov.au/energy-efficiency/water-heaters/alternatives-electri c-water-heaters/solar-water-heaters

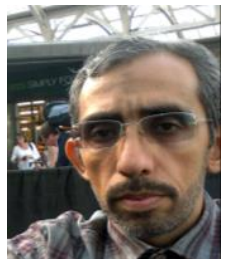

Mohammed I. Y. ALEid was born in Saudi Arabia, AlHasa, on $7^{\text {th }}$ May 1969. He got the bachelor science computer aided design granted 2007, UK Birmingham City University. He is currently retired from Jubail Industrial College after 25 years' service mostly as instructor of electromechanical and after 2007 as instructor of Manufacturing in Mechanical and Manufacturing Department. Mr. AlEid has published few research papers.

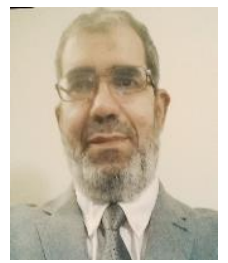

Shareef Mohammed El-Shekshaky was born in Cairo, Egypt on $13^{\text {th }}$ October 1955 . He got the bachelor of electrical power \& machines engineering from the University of Helwan / Egypt, in 1980.

He worked as an electrical engineer; installing, controlling, and Supervising electrical water pumping station with stand-by generators, trained and served in electronic war operations center in military, worked as an electrical maintenance engineer; installing electrical power and control panels, worked as an instructor and chief of sub-station maintenance department; mainly teaching electrical power engineering courses and worked currently as a teacher of electrical power engineering courses in Department of Electrical and Electronic Engineering Technology at the Jubail Industrial College in Saudi Arabia.

In addition to regular teaching and projects supervision, He has conducted a large number of special training programs to industry and was a member of different committees such as ABET Accreditation, ELET Department Council and Industrial.

Mr. El-Shekshaky Issued different publications in Jubail Industrial College Technical Journal, Volumes 1, 2 \& 3; power factor and its effects on commercial energy cost, lightning strokes and electromagnetic (bullet) train. Submitted and attended a research paper titled "ELECTROMAGNETIC (BULLET) TRAIN" at the international conference held at the Bombay Exhibition Center, Mumbai, India, (INDUCTICA Mumbai 2010) also submitted a research group paper titled "JIC Green initiative project (GIP) \# 26 at the $14^{\text {th }}$ international conference on Sustainable Energy Technologies held at Nottingham University, UK. 


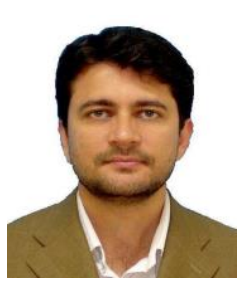

Abdul Baseer Mohammed got the PhD, Mechanical Engineering Dept., spl. in wind energy engineering, University of Pretoria, South Africa.

$\mathrm{He}$ is currently working as a lecturer in Jubail Industrial College, Saudi Arabia. The following are a few of his relevant publications.

Dr. Baseer's research interests include advanced machining technology and wind energy engineering.

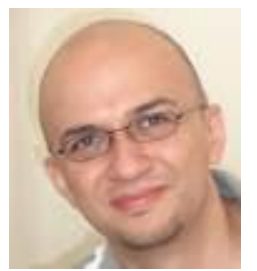

Fouad Zayadin got the M.Sc materials an metallurgical engineering graduated from Balqaa Applied University-Jordan, worked as NDT engineer in Royal Scientific Society for 6 years and then as a lecturer in Jubail Industrial College for 7 years Interested in energy and water in addition to the given specialty. 